\title{
DROSERA FILIFORMIS, D. TRACYI, AND THEIR HYBRIDS: A PHOTO ESSAY
}

JOHN BRITTNACHER • Ashland • Oregon・USA・john@carnivorousplants.org

Keywords: hybrids, Drosera filiformis, D rosera tracyi, Drosera $\times$ californica.

The taxonomic relationship of D rosera filiformis Raf. and D rosera tracyi Macf. has been mired in controversy for over a century (Rice 2011). Part of the reason for the controversy is the plants are similar to each other and quite different from the other North and South American Drosera section D rosera species (see Fleischmann et al. 2018 for species no longer considered to be in section Drosera). Another part of the reason is classical taxonomists make decisions based on dead, dried plants. The taxonomically valid differences between $D$. filiformis and $D$. tracyi are subtle. The purpose of this photo essay is to document the similarities, differences, and possibly unexpected behaviors of live plants to inform us on how to consider D. filiformis, D. tracyi, and their hybrids.

For the past eight years I have been growing and studying what could be called D rosera filiformis complex plants in order to better understand their relationships. I grow the plants outside as much as possible in Ashland, Oregon, to attempt to have them all under identical conditions. Growing USA gulf coast plants outside year-round in Ashland can be problematic owing to the elevation and low humidity allowing large daily temperature swings, potential for early and late season freezes, and relatively short growing season. I maintained backup plants in my garage under lights as much as possible. In particular, D. tracyi may exhibit no losses outside some winters and greater than 50\% others. The plants do not get as large as they would in their natural habitat. I have clones of D rosera filiformis var. floridana B.Rice (Rice et al. 2017) that do not go sufficiently dormant to be outside with below freezing temperatures and one clone of that variety that survives best outside all winter without protection.

The clones used in this study run the gamut from Atlantic coast D. filiformis var. filiformis, through a series of known and expected hybrids to definite D. tracyi as well as D. filiformis var. floridana. I have not studied D rosera Xcalifornica var. arenaria B.Rice (Rice 2017), the hybrid between $D$. filiformis var. floridana and D. tracyi nor inter-variety hybrid plants of $D$. filiformis although I do have plants I suspect are D. Xcalifornica var. arenaria (Fig. 1).

As much as possible I have used plants with good location data. Those plants are listed with the source county and state. However, doing scientific studies with clones that have been in cultivation for 40 years or more is treading on treacherous ground. To better understand the relationship between $D$. filiformis and D. tracyi and validate the use of the metrics in Rice (2011) we do have to look at all available material, especially suspect and known hybrids. The plant I have labeled "received as D. tracyi" may or may not be the pure species. Under the species description in Rice (2011) it is probably D. tracyi, but it is different from the other definite D. tracyi clones I have seen. The differences could be part of the natural variation in D. tracyi and/or how it responds to my growing conditions. D. $\times$ californica 'California Sunset' is an artificial hybrid between D. filiformis var. filiformis and D. tracyi (Robinson 1981). D. × californica 'Portland Sunrise' appears to be a complex hybrid that occurred under cultivation and more closely resembles $D$. filiformis. There are two additional hybrids that are commonly available. I received plants I will call D . × californica "FG" from two different sources but they were different. For this study I used the one from the source who had grown it longest assuming the plants from the other source would be more likely to have been propagated via seed. I also received a clone I will call D. $\times$ californica "CG" from the more reliable source. Both clones are very similar to D. 'California Sunset' except they are more compact 


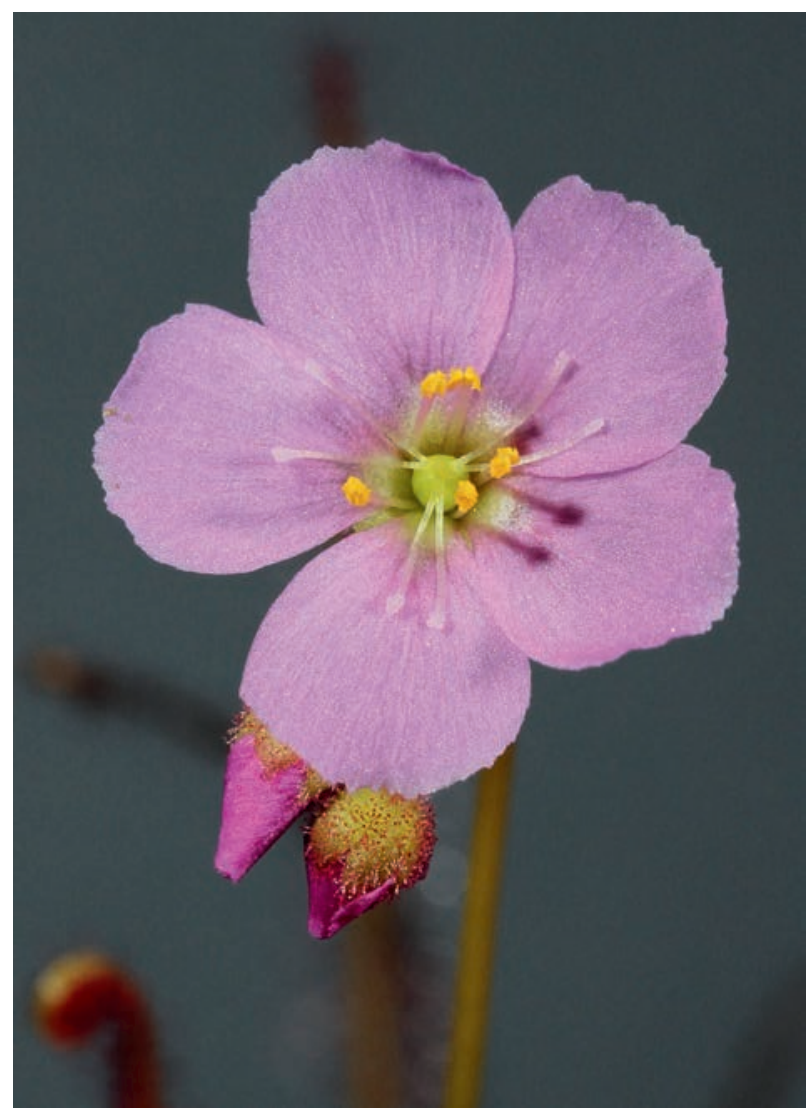

Figure 1: Flower of a plant that appears to be from a Drosera $\times$ californica var. arenaria hybrid swarm. The plant is smaller and darker red than Drosera $\times$ californica var. arenaria as described by Rice (2017) but according to taxonomic rules, backcross hybrid progeny maintain the hybrid name. It was a seed-grown plant from a selection of large supposed D. filiformis var. floridana from Washington County, Florida.

plants and can be, but not always, somewhat redder under my conditions. D. × californica "FG" has slightly different flowers.

Figure 2 is a photo taken in mid-June of five representative clones grown outside. Drosera filiformis var. floridana "white flower" is consistently that red. It does not get as tall as the other D rosera filiformis var. floridana clones I have and is winter hardy in Ashland. The D. filiformis var. filiformis, Columbus County, North Carolina, plants tend to be larger and paler than the New Jersey plants. The D. tracyi plants in the photo are not quite blooming size.

Closeup images of leaves of the clones used in this study are shown in Figures $3 \& 4$. The photos are at the same scale. The leaves of what I consider canonical D. tracyi tend to be wider and to be more densely covered with shorter tentacles than are the leaves of D rosera filiformis and the hybrids. The tentacle heads are clear to pale red. The D. tracyi, Hanrahan Ranch plant has very pale tentacle heads. The Hanrahan Ranch, a 20-acre private CP reserve in Baldwin County, Alabama (Miller 2013), has a mix of D. tracyi with nearly clear to pale red tentacle heads plus anthocyanin- 


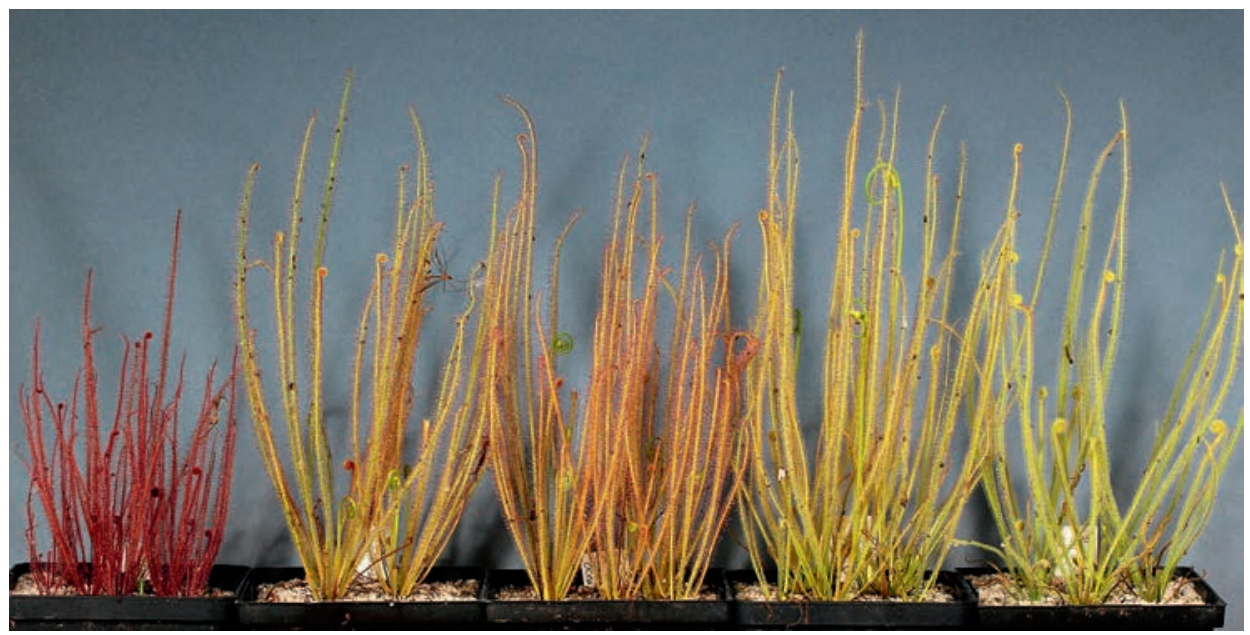

Figure 2: Drosera filiformis complex plants. Left to right: $D$. filiformis var. floridana "white flower", Washington County, FL; D. filiformis var. filiformis, Columbus County, NC; $D$. filiformis var. filiformis, Ocean County, NJ; D. × californica 'California Sunset'; $D$. tracyi, Hanrahan Ranch collection.

free (no red pigment) plants and occasional hybrids with D. 'California Sunset'. The D. tracyi "unknown source" plant can put out D. filiformis-like leaves in the spring and young leaves can have dark red tentacle heads. I have observed similar D. filiformis-like leaves on herbarium specimens of D. tracyi so do not know what to think of the plant. In the hybrids except for D. $\times$ californica 'Portland Sunrise', the tentacle heads become paler as the leaves age. Similar aged leaves of D. filiformis do not become noticeably paler.

Leaf photo dates and measurements taken from the photos are shown in Table 1. Rice (2011) used an index of tentacle length/leaf width to categorize D. filiformis complex plants. The $\pm 1 \sigma$ values for the tentacle length/leaf width for $D$. tracyi were 0.9-2.3 and for D. filiformis (both varieties lumped) were 2.6-4.8. His measurements were taken from herbarium specimens. It appears these numbers need to be adjusted for live specimens although the trends are the same. The advantage of using the ratio in studies is the index has no units, meaning it doesn't matter how you make the measurements. I find it convenient to measure off photos and scans on a computer screen. I measure the typical maximum distance between tips of tentacles across a leaf then use a formula subtracting the width of the leaf lamina and dividing by two to get the tentacle length. The examples in this paper are of selected typical leaves while Rice likely used a larger selection of leaves for each plant giving his data a larger variance.

Closeup images of the flowers of most of the clones used in this study are shown in Figures 5 \& 6. The photos are not to scale. As would be expected, the flowers of D. tracyi were the largest. The hybrid flowers were generally intermediate between $D$. tracyi and D. filiformis var. filiformis with larger plants of $D$. filiformis var. filiformis from North Carolina having flowers the same size as smaller flowered hybrids. The D. filiformis var. floridana flowers were the smallest. Note that the styles of $D$. tracyi and most of the hybrids are longer than those of $D$. filiformis. This is a key difference between the species and it results in D. tracyi and the similar hybrids having lower rates of self-pollination. What stands out in the photos is the flower petals of D. × californica "FG" and D. filiformis var. filiformis, Columbus County, NC, are relatively wider than comparable clones. If 


\begin{tabular}{|c|c|c|c|c|c|}
\hline Image & Clone & $\begin{array}{c}\text { Leaf } \\
\text { Photo Date } \\
\text { yyyymmdd }\end{array}$ & $\begin{array}{l}\text { Max Tentacle } \\
\text { Length }(\mathrm{mm})\end{array}$ & $\begin{array}{c}\text { Max Leaf } \\
\text { Width }(\mathrm{mm})\end{array}$ & $\begin{array}{l}\text { Tentacle/Leaf } \\
\text { Width (mm) }\end{array}$ \\
\hline a, A & $\begin{array}{l}\text { D. tracyi, Hanrahan } \\
\text { Ranch collection }\end{array}$ & 20140705 & 1.9 & 2.0 & 1.0 \\
\hline $\mathrm{b}$ & $\begin{array}{l}\text { D. tracyi, Walton } \\
\text { County, FL. }\end{array}$ & 20140705 & 1.8 & 1.9 & 0.9 \\
\hline $\mathrm{c}, \mathrm{B}$ & $\begin{array}{l}\text { Received as D. } \\
\text { tracyi, unknown } \\
\text { source }\end{array}$ & 20170725 & 1.6 & 1.2 & 1.3 \\
\hline d & Earlier leaf of (c) & 20170704 & 2.6 & 0.9 & 2.8 \\
\hline $\mathrm{e}, \mathrm{C}$ & $\begin{array}{l}\text { D. } \times \text { californica } \\
\text { 'California Sunset' }\end{array}$ & 20170725 & 1.7 & 1.4 & 1.2 \\
\hline f, D & $\begin{array}{l}\text { D. × californica } \\
\text { "CG" }\end{array}$ & 20140705 & 1.8 & 1.6 & 1.1 \\
\hline g & Older leaf of (f) & 20140821 & 1.7 & 1.4 & 1.2 \\
\hline$h, E$ & $\begin{array}{l}\text { D. × californica } \\
\text { "FG" }\end{array}$ & 20140705 & 2.2 & 1.7 & 1.3 \\
\hline $\mathrm{i}$ & Older leaf of (h) & 20140821 & 1.5 & 1.5 & 1.0 \\
\hline $\mathrm{j}, \mathrm{F}$ & $\begin{array}{l}\text { D. } \times \text { californica } \\
\text { 'Portland Sunrise' }\end{array}$ & 20140701 & 3.0 & 0.9 & 3.3 \\
\hline $\mathrm{k}$ & Older leaf of (j) & 20170727 & 2.5 & 1.2 & 2.1 \\
\hline $1, \mathrm{G}$ & $\begin{array}{l}\text { D. filiformis } \\
\text { var. filiformis, } \\
\text { Columbus County, } \\
\text { NC }\end{array}$ & 20140707 & 2.2 & 1.4 & 1.6 \\
\hline $\mathrm{m}$ & Older leaf of (i) & 20170727 & 2.8 & 1.3 & 2.1 \\
\hline $\mathrm{n}, \mathrm{H}$ & $\begin{array}{l}\text { D. filiformis var. } \\
\text { filiformis, inland } \\
\text { Ocean County, NJ }\end{array}$ & 20140703 & 2.6 & 1.1 & 2.3 \\
\hline $\mathrm{o}, \mathrm{J}$ & $\begin{array}{l}\text { D. filiformis var. } \\
\text { filiformis, coastal } \\
\text { Ocean County, NJ }\end{array}$ & 20140703 & 2.3 & 1.3 & 1.7 \\
\hline $\mathrm{p}$ & Older leaf of (o) & 20170727 & 2.2 & 1.1 & 2.0 \\
\hline $\mathrm{q}, \mathrm{K}$ & $\begin{array}{l}\text { D. filiformis var. } \\
\text { floridana, unknown } \\
\text { location }\end{array}$ & 20130912 & 1.8 & 0.6 & 2.9 \\
\hline $\mathrm{r}, \mathrm{L}$ & $\begin{array}{l}\text { D. filiformis } \\
\text { var. floridana } \\
\text { "white flower", } \\
\text { Washington Co., } \\
\text { FL }\end{array}$ & 20170616 & 2.1 & 0.6 & 3.4 \\
\hline
\end{tabular}



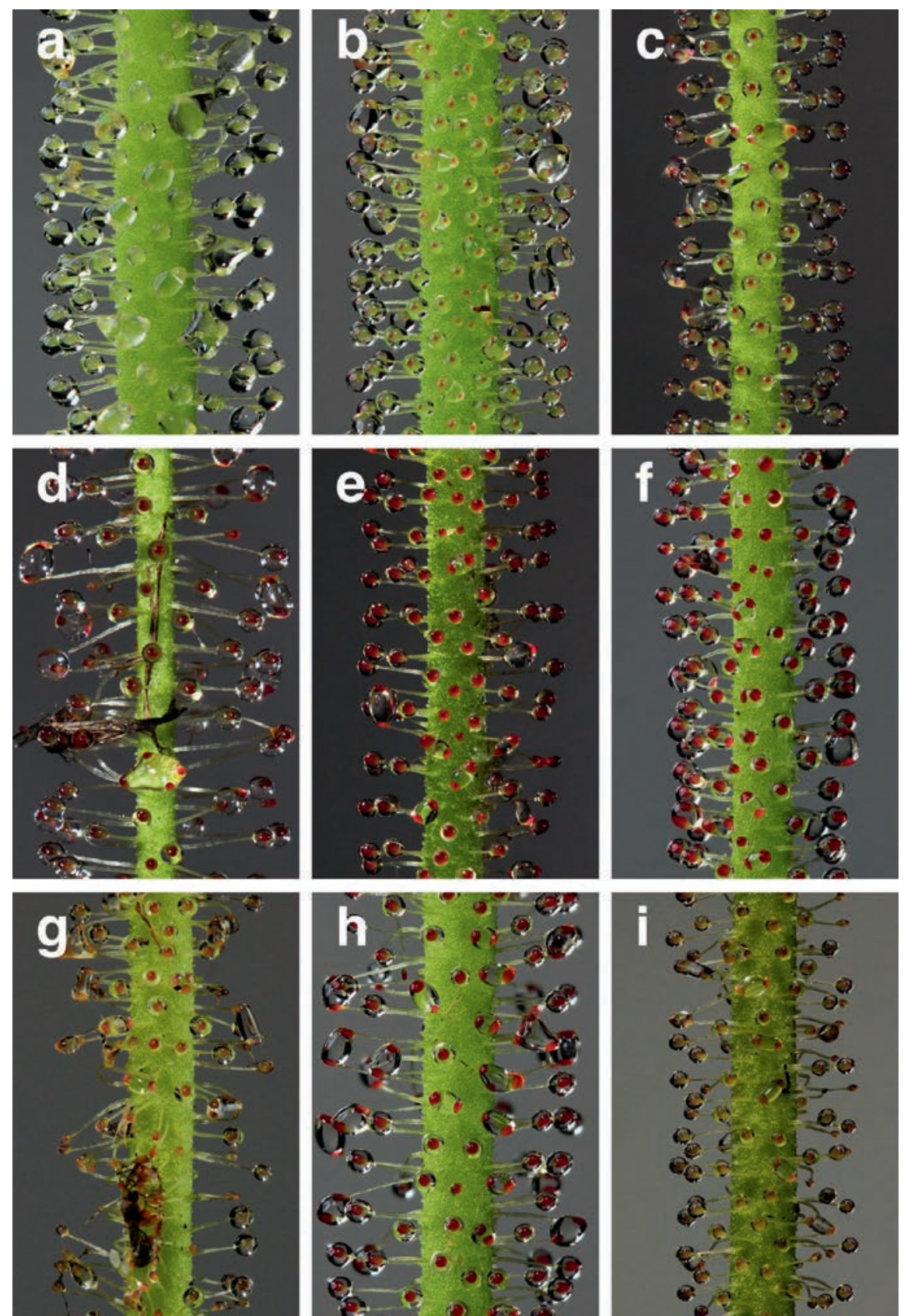

Figure 3: Leaves of Drosera tracyi and $D$. tracyi $\times$ filiformis hybrids. Typical early summer leaf unless otherwise noted. (a) D. tracyi, Hanrahan Ranch collection. (b) D. tracyi, Walton County, FL. (c) Received as D. tracyi, unknown source. (d) Earlier leaf of (c). (e) D. $\times$ californica 'California Sunset'. (f) D. × californica "CG". (g) Older leaf of (f). (h) D. × californica "FG". (i) Older leaf of (h). Each image is $7 \mathrm{~mm} \times 10.5 \mathrm{~mm}$. 

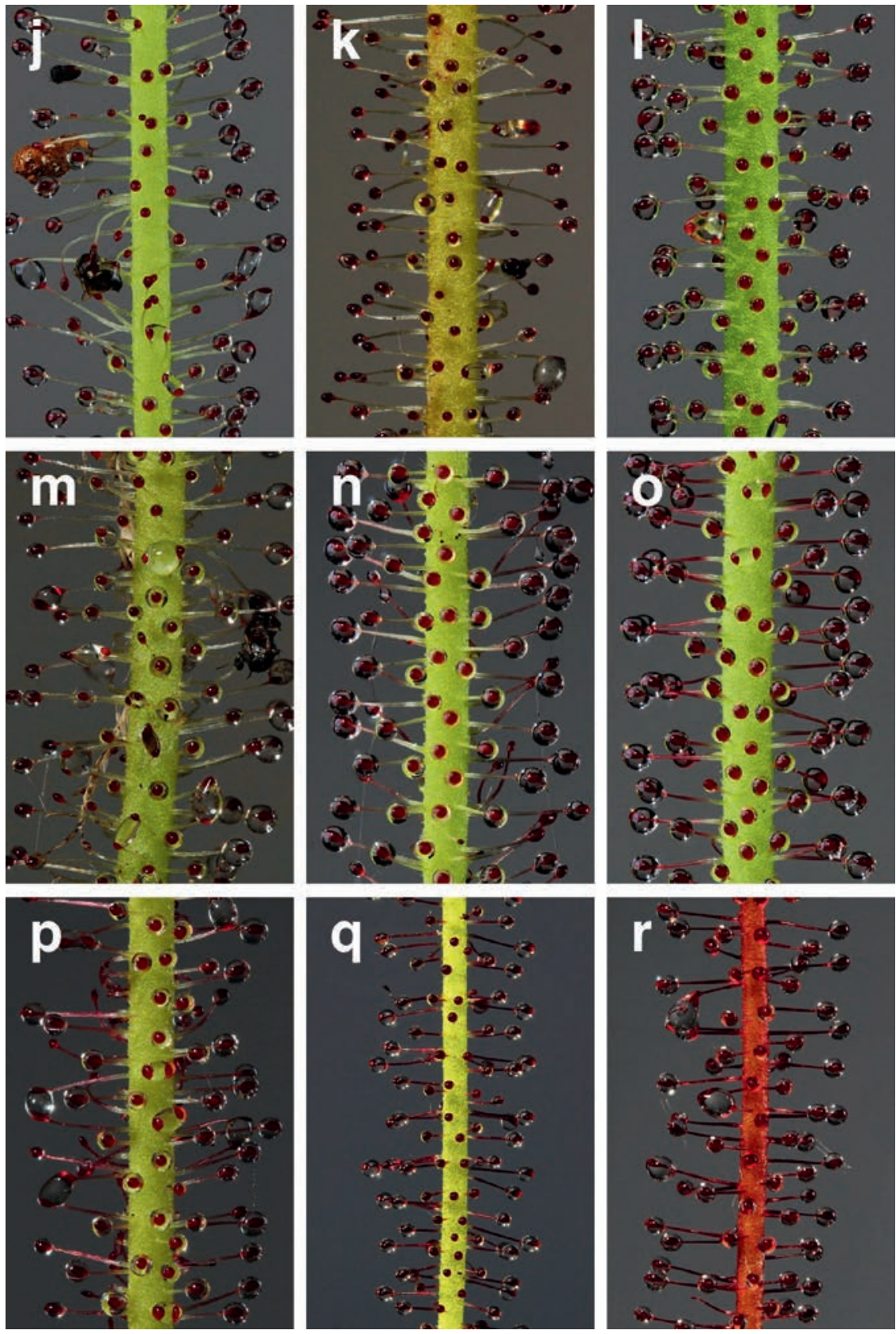

Figure 4: Leaves of Drosera filiformis and D. tracyi $x$ filiformis hybrids. Typical summer leaf unless otherwise noted. (j) D. × californica 'Portland Sunrise'. (k) Older leaf of (j). (I) D. filiformis var. filiformis, Columbus County, NC. (m) Older leaf of (i). (n) D. filiformis var. filiformis, inland Ocean County, NJ. (o) D. filiformis var. filiformis, coastal Ocean County, NJ. (p) Older leaf of (o). (q) D. filiformis var. floridana, unknown location. ( $r$ ) D. filiformis var. floridana "white flower", Washington County, FL. Each image is $7 \mathrm{~mm} \times 10.5 \mathrm{~mm}$. 

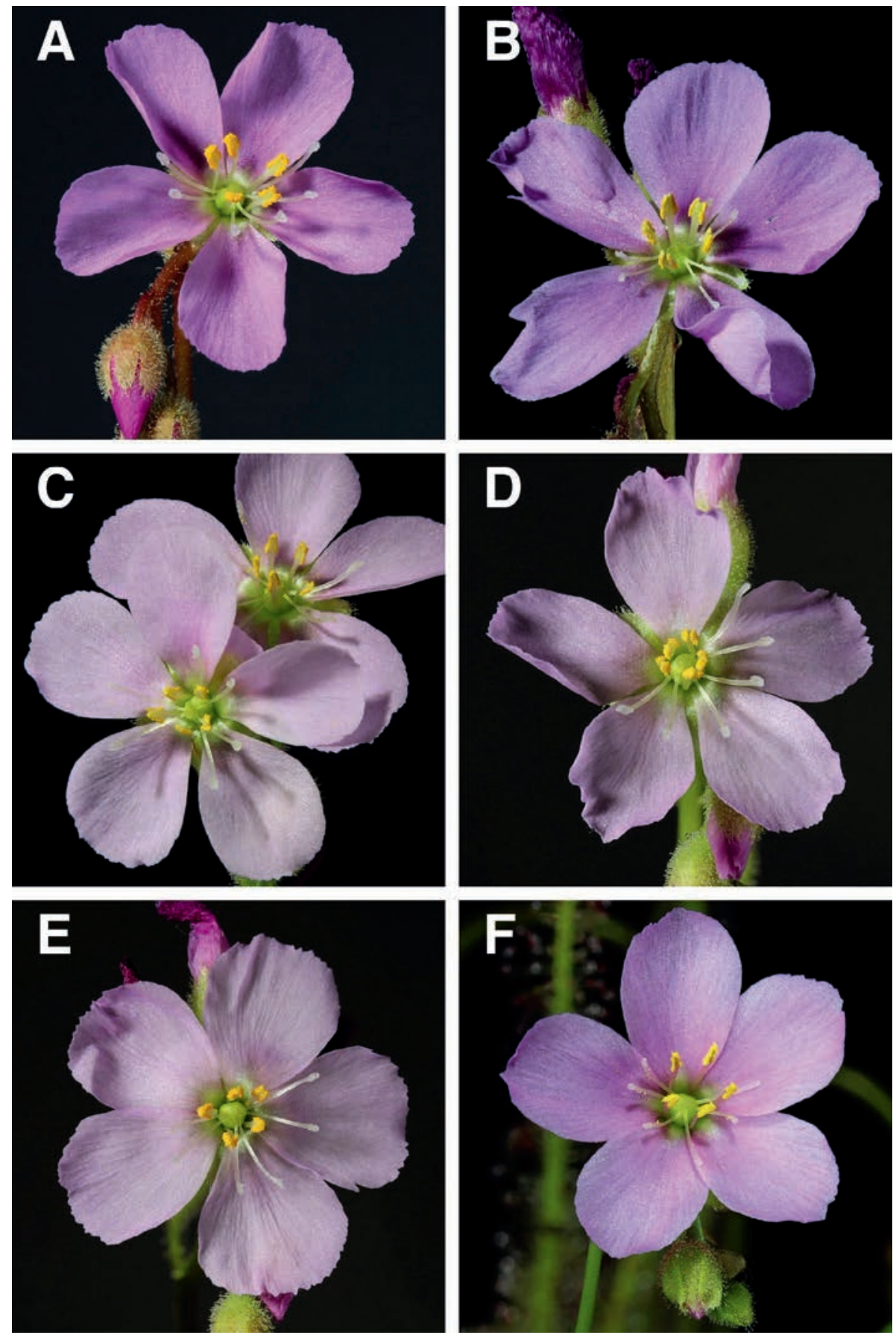

Figure 5: Flowers of Drosera tracyiand D. tracyi $\times$ filiformis hybrids. (A) D. tracyi, Hanrahan Ranch collection. (B) Received as D. tracyi, unknown source. (C) D. $x$ californica 'California Sunset'. (D) D. × californica "CG". (E) D. × californica "FG". (F) D. × californica 'Portland Sunrise'. Images not to scale. 

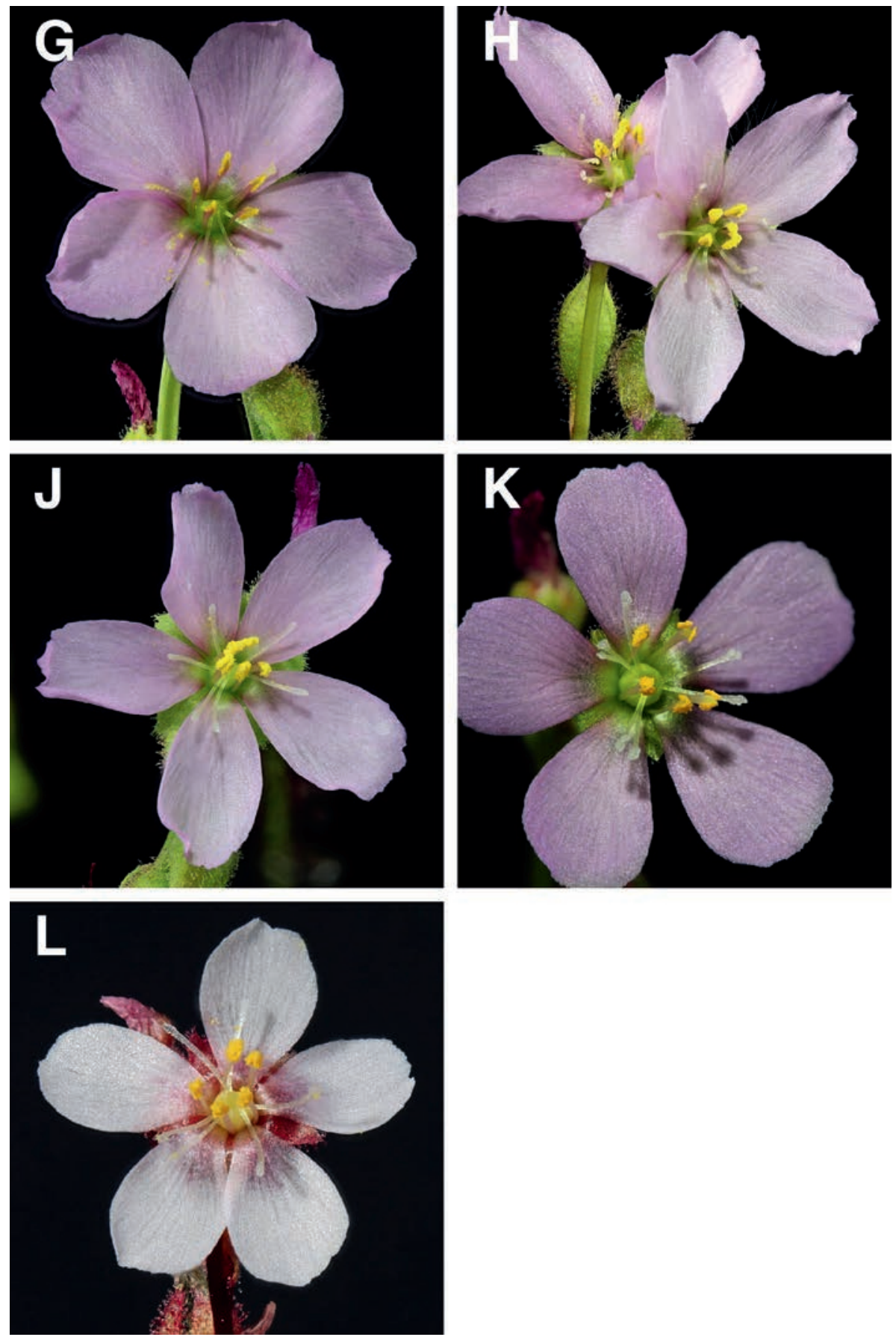

Figure 6: Flowers of Drosera filiformis. (G) D. filiformis var. filiformis, Columbus County, NC. $(\mathrm{H})$ D. filiformis var. filiformis, inland Ocean County, NJ. (J) D. filiformis var. filiformis, coastal Ocean County, NJ. (K) D. filiformis var. floridana, unknown location. (L) D. filiformis var. floridana "white flower", Washington County, FL. Images not to scale. 
anything, I would have expected the "CG" plants to have similar petals to the North Carolina plants if any did. Unfortunately, there are no officially published plant descriptions, photos or source information for the hybrids in question.

My reasons for studying the D rosera filiformis complex are I think the plants have an interesting evolutionary story to tell and formal taxonomy is impeding a full understanding of the plants. How we name plants molds how we think about them. D. filiformis var. filiformis andD. tracyi are as good a species as you can get in a group of species that can interbreed and probably do at an extremely low level. I would add D. filiformis var. floridana to that list being a species as well. Unfortunately, it is a species in danger of going extinct by hybridization with $D$. tracyi. There are very few populations and when they occur near D. tracyi they produce hybrids (Rice 2010, 2017; Rice et al. 2017).

Acknowledgements: I thank Damon Collingsworth, Djoni Crawford, Peter D’Amato, Jason Ksepka, Kevin Tarner, Harry Tryon, and Mike Wilder for providing plants or seeds, Victor Holland and Mark Todd for giving me a tour of D rosera filiformis sites in North Carolina, Djoni Crawford for assistance on the manuscript, and Barry Rice for discussion and comments on the manuscript.

\section{References}

Fleischmann, A., Minatel Gonella, P., and Rivadavia, F. 2018 A new sectional name for the Brazilian tetraploid clade of D rosera subgenus D rosera. Carniv. Pl. Newslett. 47(1): 4-9.

Miller, J. 2013. Memories of Bob Hanrahan. Carniv. Pl. Newslett. 42(3): 92-93.

Rice, B.A. 2010. Noteworthy collections: Florida. Carniv. Pl. Newslett. 39(3): 91.

Rice, B.A. 2011. The thread-leaf sundews D rosera filiformis and D rosera tracyi. Carniv. P1. Newslett. 40(1): 4-16.

Rice, B. 2017. Naturally occurring hybrids of North American D rosera. In: Lowrie, A., Robinson, A., Nunn, R., Rice, B., Bourke, G., Gibson, R., McPherson, S., and Fleischmann, A. D rosera of the World, volume 2, Oceana, Asia, Europe, North America. Poole, Dorset, England: Redfern Natural History Productions.

Rice, B., Robinson, A., and Fleischmann, A. 2017. D rosera of North America. In: Lowrie, A., Robinson, A., Nunn, R., Rice, B., Bourke, G., Gibson, R., McPherson, S., and Fleischmann, A. D rosera of the World, volume 2, Oceana, Asia, Europe, North America. Poole, Dorset, England: Redfern Natural History Productions.

Robinson, J.T. 1981. New CP Cultivar Received in 1980. Carniv. Pl. Newslett. 10(4): 95.

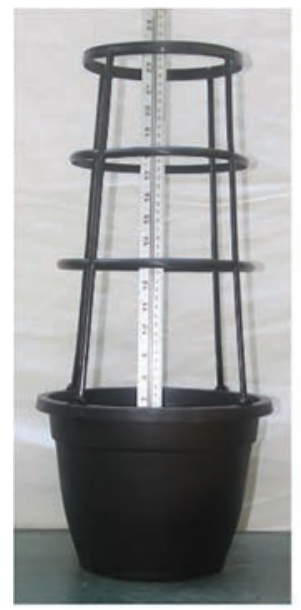

\section{Ferocious Foliage.com} Custom Tissue Culture Laboratory

\section{Terrific alternative to a hanging basket. \\ Pots are $10^{\prime \prime}$ in diameter, $71_{4}^{\prime \prime}$ tall with a $\sim 1.75$ gallon capacity. Terraces are $14 \frac{112 "}{\prime \prime}$ tall. \\ info@ferociousfoliage.com

$$
\$ 5.00 \text { each }+\mathrm{S} / \mathrm{H}
$$$$
\text { Ferocious Foliage }
$$$$
\text { P.O. Box } 458
$$$$
\text { Dahlonega, GA } 30533
$$

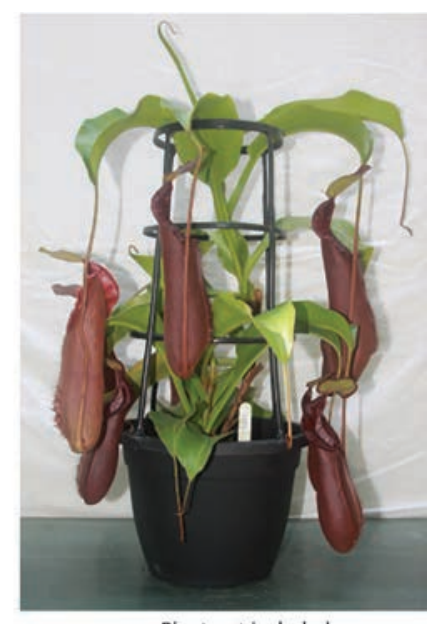

Plant not included 